\title{
松本市「工芸の五月」における 運営実態の分析
}

\section{工芸を活用したまちづくり手法に関す} る研究

\section{一ノ瀬 彩—— * 1 \\ キーワード : \\ 工芸, まちづくり, 市民組織, 運営実態}

Keywords:

Crafts, Regional vitalization, Nonprofit organization (NPO), Actual management
ANALYSIS OF ACTUAL MANAGEMENT
IN MATSUMOTO CRAFT MONTH

A research on a method for the regional vitalization with crafts

\section{Aya ICHINOSE}

The present work aims to investigate Matsumoto Craft month to obtain the fundamental knowledge of the event including the elements of town planning for the regional vitalization with crafts. We have analyzed the management data of Matsumoto Craft Month for 7 years from management organization and the contents of the plan. We found that the cooperation with experts, can allow the management board of Matsumoto Craft Month to expand the planning capability and their expertise. Furthermore, we have derived eight types of the plan. We believe these results will provide the fundamental knowledge fostering the regional vitalization with crafts.

\section{1. はじめに}

地域資源の潜在価值を芸術的な要素を媒体として伝える文化創造 活動が市民主体のまちづくりとして注目されている ${ }^{1)}$ 。芸術作品の 中でも工芸註 ${ }^{1)}$ は人々の生活を豊かにする暮らしの道具として身近 な存在であるうえ地域の歴史文化との親和性も高く、地場産業や伝 統工芸によるまちづくりが行われている ${ }^{2)}$ 。近年では伝統工芸に限 らず市民主体のクラフトフェアも急増しているが註2)、多くのクラフ トフェアは単発のまちおこしイベントに止まる。一方、長野県松本 市の「クラフトフェアまつもと」註 ${ }^{3}$ は全国初のクラフトフェアとし て約 30 年の長期的運営に成功し、工芸のまち松本の魅力を発信する イベント「工芸の五月」へ発展した。まちづくり要素を含むイベン トへ発展した初めてのクラフトフェアとして注目を集め地域経済へ の波及効果 ${ }^{3)}$ や都市景観形成 ${ }^{4)}$ の観点から研究が行われてきた。

本研究は、工芸によるまちづくり手法を確立するため「工芸の五 月」に関し工芸活用の観点から特徵的な運営手法を抽出する。本論 文では、一定期間実施されるまちづくり要素を含むイベントの継続 的取り組み手法を狭義のまちづくり手法と定義する。そこで、「工芸 の五月」が開始された 2007 年から 2013 年の 7 年の「工芸の五月」 の長期運営データ註4) から運営組織および企画の分析を行う。

\section{2.「工芸の五月」の概要}

長野県松本市は、古く江戸時代から城下町ならではの職人の技術 を土台に工芸の技術が育まれた地域である。昭和初期には柳宗悦が 提唱した民藝運動が根付いた地域で、中町の歴史的建造物の保存再
生活用によるまちづくりに影響を与えている ${ }^{3)}$ 。市内にも工芸品を 扱う店舗や木工家具工房、県内には工芸家が多く集まる。このよう な背景から 1985 年に日本初のクラフトフェアまつもとが県の森公 園で開催された。その後、2007 年の松本市制 100 年を記念して、工 芸のまち松本の魅力を発信する「工芸の五月」へと発展を遂げた。 毎年五月の約 1 ケ月間を工芸月間とし、松本市を中心に美術館、博 物館等の市内 50 以上の会場で工芸の企画展が開催される。2014 年 にはクラフトフェアまつもとが開始されて 30 年目の節目を迎え、県 内外だけでなく海外からも多数の参加者が訪れるまでに成長した。

\section{3. 運営組織の分析}

\section{1 運営組織の形成過程}

図 1 には 1985 年から現在に至るまでの「工芸の五月」の歴史的変 遷と組織形成過程を示した。クラフトフェアまつもとは、工芸家な ぞの市民有志により県の森公園で開催されたのが始まりである。 1987 年には市民組織「松本クラフト推進協会」(以下推進協会と略 す）が発足し、クラフトフェアまつもとを主催してきた。より多く の来場者に松本のまちを巡ってほしいという思いから、ギャラリー の経営者や推進協会に所属する工芸家らが中心となりクラフトフェ アまつもとが開催される 5 月の一ヶ月間に工芸を切り口としたまち の魅力を発信するイベントを計画し、2007 年松本市制 100 年を機に 推進協会が主体となって「工芸の五月」を開始した。その一方で、 クラフトフェアまつもとの来場者の増加による開催時の交通問題が 深刻化したことで、2008 年 7 月に行政との連携による交通対策を開

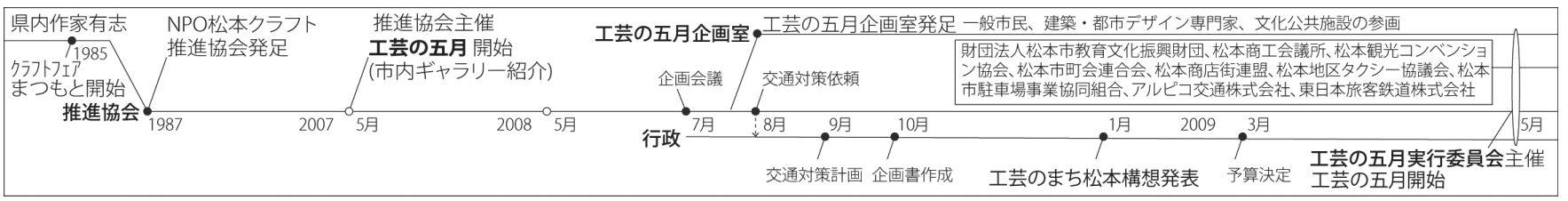

図 1 工芸の五月の変遷と組織形成

茨城大学工学部都市システム工学科 助教

（广 316-8511 茨城県日立市中成沢町 4 丁目 12-1） 
始した。松本市は工芸の五月の経済活性・観光振興効果 ${ }^{\text {䛨 }}$ )に着目し 工芸を松本市のまちづくりのテーマとして掲げた辣 6 。ささらに企画を 強化するため、外部専門家を集めて工芸の五月企画室 (以下企画室) が発足した。2009 年より推進協会が主体となって、行政や交通関連 の民間企業、文化芸術、商工観光関連の団体などと連携し、「工芸の 五月実行委員会」(以下委員会と略す)が立ち上げられた。以上のよ うに、市民有志や工芸作家を中心とした運営組織であった「松本ク ラフト推進協会」は、初動期の運営実績をもとに、行政、交通関連 の民間企業、美術館などの文化芸術団体と連携を進めた。開催規模 の拡大や内容の変化に伴い深刻化した交通問題などの課題に柔軟に 対応し、継続的な運営に成功してきたことが明らかになった。

\section{2 組織体制}

図 2 には現在の委員会の組織体制を示した。運営組織は「企画室」 と「事務局」から構成される。委員会のメンバーは、推進協会を主 体とし、行政、交通関連の民間企業、文化芸術、商工観光関連の団 体註7)から構成される。図 2 で示したように、クラフトフェアまつも との運営経験から推進協会の構成員は企画室と事務局を兼任してい るが、企画室には、新たに工芸家やデザイナー、編集者、写真家、 建築・都市デザインなどの専門家が参加し、企画機能を強化してい る。企画室の役割は、工芸の五月の企画・プロモーションである。 企画室の特徵は、民間企画の審査だけでなく、民間と連携して地場 産業や作家紹介、食材や飲食店を活用する企画を立案している。一 方、事務局は、事務・会計の他、交通対策を行う。2013 年には利用 者の市内の回遊性を高めるため、1 日バス乗車券制度、回遊バスと シャトルバスの運行を開始した。公共交通の活用による渋滞対策は 推進協会に所属する都市交通の専門家と行政が事務局として立案し、 行政が民間企業にバス運行要請や借り上げを行う。以上のように、 工芸の五月実行委員会は、推進協会にはなかった分業体制を敷いた。 さらに、企画室は専門家を加え従来の企画機能を強化した。

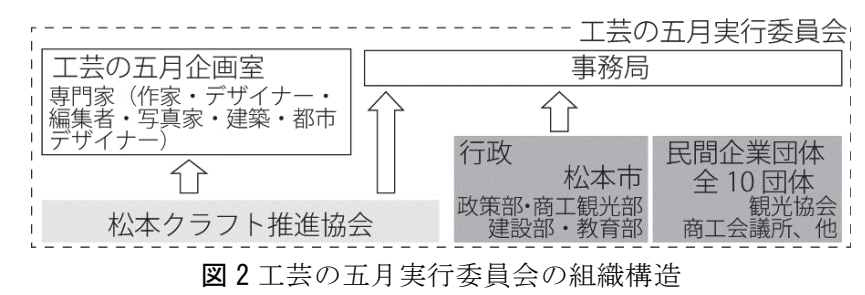

\section{4. 開催企画の分析}

\section{1 企画内容の変遷}

「工芸の五月」が開始された 2007 年から 2013 年までの 7 年間の 間に開催された全 306 企画註8) を対象に開催企画の分析を行った。特 に、企画を実施する上で重要な場所、工芸分野、企画形態、ワーク ショップコンテンツについて 7 年間の企画の変遷をまとめた。

まず、表 1 には企画開催場所の分析結果を示す。開催場所の多く は市内外のギャラリーや物販店、飲食店などの個店経営店舗の他、 2009 年以降は寺社や空き家(蔵)、老舗温泉旅館などの民間施設であ った。公共施設の多くは美術館や歴史的建造物を活用した博物館や 公園などであり、2009 年以降は市内の文化施設が開催期間を合わせ て工芸に関わる企画展を一斉に開催していた。以上の分析から、工 芸の五月の開催場所は市内の商業地域にある民間施設を中心としな がら市内に立地するほとんどの文化施設や公園、湧水や水路などが 点在する住宅地、空き店舗がみられる駅周辺の商店街に広がりをみ
せていることが示された。次に、図 3 には、工芸分野ごとの企画の 推移を示す。企画立案に委員会の企画室が関わる場合と、民間団体 のみで企画立案する場合に分けて示した。工芸の種類には、衣類、 食器、家具、雑貨、素材 (麻・毛・蓇・木)がみられ、食器や雑貨を 対象とした企画が多い。企画室が関わる企画には素材に着目したも のが見られるが、民間にはない。これは、企画室は民間では扱い難 い素材に関する企画を行い、工芸への関心や理解を深める役割を果 たすことで民間と相補的な運営を行っていることを示している。企 画形態は、展示、展示・販売、ワークショップ（以下WS と略す）と 複数箇所開催されるもの、工芸を介した街あるきがあり、滞留型企 画と回遊型企画に大別できる (図 4)。滞留型企画は、独立した単体 企画である。一方、回遊型企画は、企画者の意図のもと相関のある 散策ポイントや集合店舗から構成される企画である。この結果をも とに、図 5 には、滞留型企画および回遊型企画ごとに類型化した企 画の推移を示した。まず、全企画を民間主体と推進協会が関わる企 画に分類する。次に滞留型企画と回遊型企画に分類する。滞留型企 画は、企画形態から展示のみ、展示・販売、WS の 3 つに分類できる ので、それぞれの企画数を数えて図 5 を得た。その結果、企画数は 企画者に関わらず年々増加傾向にあり、ギャラリーや物販店等の民 間の企画は、滞留型の展示販売を行う場合が約 8 割を占める。企画 室が関わるものでは展示やWS が多く、特に WS は民間の約 6 倍とな っている。企画室は展示販売を中心とする民間企画の審査だけでな く、工芸家の紹介と地域の食材や飲食店を民間に紹介しながら工芸 作品を使う機会をまち中に企画立案する役割を持つ。一方、回遊型 企画には 2009 年から外部専門家が参画する企画がみられ、2012 年 より民間でも企画がみられるようになった。企画内容は食器などを 飲食に使用しながらまちを巡るまちなか回遊と、市内数店舗が同一 のテーマで工芸を展示販売し店舗を巡る店舗回遊の二つがある。こ のように、近年、意図的に人々を回遊させようと試みる企画が増え ている。従来の滞留型の工芸イベントから脱却し、まちづくりへ発 展させようとする企画者の意識の変化を表していると考えられる。 さらに企画室が関わることで急増したWS に着目し詳細に調査した。 食器や家具、雑貨、素材といった工芸への関心を深めるため、食器 などを作る [制作]、食器を用いた[飲食]、工芸の技術や成り立ちを 知る[教育]の 3 つに類型化できた(図 6)。

\section{2 企画の運営体制}

企画内容の類型化により新たな企画タイプを導出し、それぞれの タイプの運営体制を分析した (表 2)。企画タイプの導出では、まず、 民間や企画室などの企画主体に着目して類型化し、1 4 の企画タイ プを導いた。次に滞留型と回遊型の企画形態ごとに類型化すること で、最終的に 8 つタイプを導出した。図 7 には、表 2 で示した各 企画タイプの運営体制を図示した。表 2 に示したように、最も多い 企画タイプ 1-1 は民間主体で滞留型企画を行うもので全体の約 $60 \%$ 以上を占める。図 7 に示したように、企画室は審查を行ない、商店 街などの民間が独立に企画・運営するものである。主催者が企画を立 案することが多いのは特徵的な結果と言える。これは、企画室が市 内の工芸の展示販売情報をとりまとめて掲載した工芸マップや公式 ガイドブックを通した松本市の工芸を活用した観光イメージ作りや、 民間への作家の紹介を行い、民間の参入を容易にしているためであ る。特に、工芸作家紹介では、毎年 1500 件以上あるクラフトフェア 
表 1 開催場所の種類(数字は開催総数)

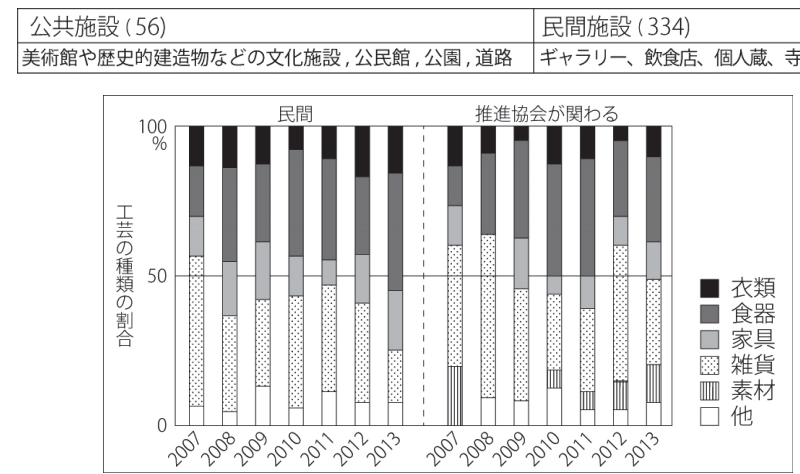

図 3 工芸の分野別にみた企画の推移

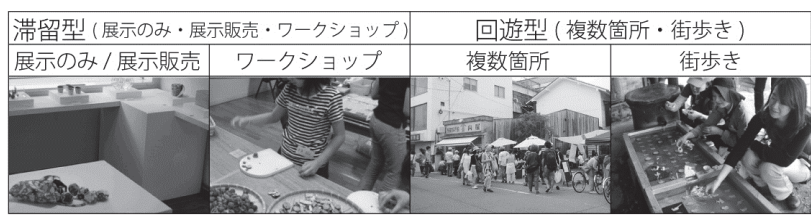

図 4 企画形態

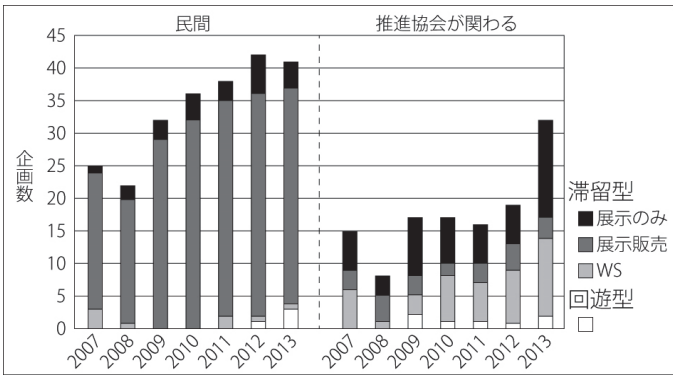

図 5 企画形態の推移

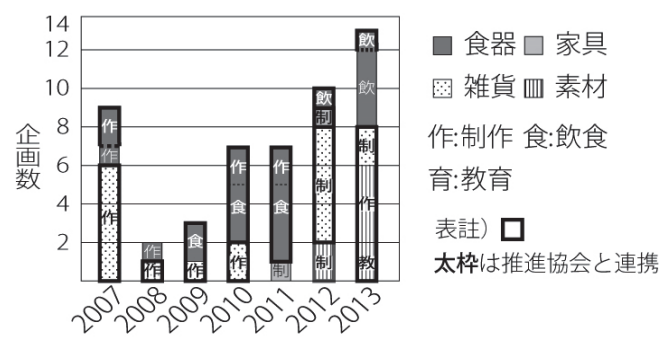

図 6 ワークショップ内容の推移

まつもとへの出展応募を介して全国の作家との交流を深めることで、 多様な分野の作家を民間に紹介寸ることが可能になった。企画室が 民間企画にあわせた企画のコーディネートを行うことは、民間が参 加しやすい環境をつくるばかりでなく、年々増加する企画の質を維 持する効果もある。このように、企画室と民間が相補的に協力する ことで、質の高い継続的な運営が実現されている。また、企画タイ プ 1-2 は民間が主体で行う企画のうち回遊型企画を行うものである。 分析例「六九クラフトストリート」は、空き店舗がみられる商店街 の通りに面寸る 5 店舗で長野県内外の作家の展示・販売が行われる 店舗回遊型の企画である。図 7 のち 1-2 民間一回遊に示したように、 企画者は商店街の空き店舗にギャラリーを構えた工芸家を中心に商 店会が立案し、企画室が審査することで開催されている。従来、県 の森公園に限定されていた民間が主体となった滞留型の工芸販売を 松本市内の商店街にまで広げた特徴的な企画であると言える。さら
に民間企業の参入が促進されたメカニズムを工芸活用の観点から考 察する。まず、民間の大部分を占めるギャラリーは工芸作品を展示・ 販売する機能がある。そのため、工芸企画との親和性は高く、作家 紹介を行う企画室との連携も進みや寸い傾向がある。また、飲食店 は、直接、工芸作品を販売する機能はないが、推進協会が食器や椅 子など備品に活用可能な工芸作品を紹介寸ることで、食と工芸を融 合させた企画立案を可能としている。このように工芸の持つ特性に より、民間企業の参入を促進する環境にあると考えられる。企画夕 イプ 2 および 3 は、クラフトの歴史的な背景や地域資源の紹介など、 一見して民間が取組みにくい萌芽的な企画について企画室が直接運 営に関わるものである。企画タイプ 2-1 は企画室と民間が連携して 滞留型企画を行うものであり、2011 年から継続して共同運営される。 この企画は地元の工房の工芸家らによる器を用いて、地元の食品販 売店や飲食店にて地場産品を飲食するもので、食器や食品・酒など の作り手と交流しながら工芸に触れることができる(図 7:2-1 企画 室十民間-滞留)。企画タイプ 2-2 は企画室と民間が連携して回遊型 企画を行うものであり 2011 年からみられる。この企画は、工芸家に よる作品を美術館で展示した後にまち中の店舗に拡散し、展示・販 売を行なう店舗回遊型である。展示までは企画室と美術館 (文化施 設)が企画立案し、展示販売は民間に託されている(図 7:2-2 企画室 十民間-回遊)。企画タイプ 3-1 は企画室と文化施設が連携し滞留型 企画を行うものであり 81 の企画がみられた。文化施設と企画室が企 画立案し、文化施設が主催する仕組みである(図 7:3-1 企画室十公共 一滞留)。分析例「くらし、いのり」では開催場所である司祭館の歴 史的背景を想起させる作品を工芸家らが展示することで、建物の特 徴を生かした空間演出を行う。企画タイプ 3-2 は企画室と文化施設 専門家が連携して回遊型企画を行うもので 2 ある。分析例「みずみ ずしい日常」は市内に点在する湧水などの景観資源を楽しむ「みず さじ」などの工芸作品提案するまちなか回遊型の企画である。企画 室は専門家や工芸家をコーディネートし、美術館と連携して企画立 案をしている(図 7:3-2 企画室+行政+専門家-回遊)。企画タイプ 3-3 は、企画室は行政と大学のつなぎ役として回遊型企画を支援す るもので、2013 年からクラフトフェアの 2 日間のまちなかの回遊性 の向上と公共空間の活用を目的に開始された。分析例「すわりまわ る」はまちなかに点在する公園などに複数の休㕷スポットを設え、 工芸家による作品展示やWS を実施する (図 7:3-3 企画室十行政十大 学-回遊)。推進協会や企画室ではこのように民間が取組みにくい回 遊型企画のような萌芽的な企画の取り組みも積極的に行う。企画夕 イプ 4 は企画室の前身である推進協会が県内外の工芸作品を募集す る滞留型企画で中心的イベントである(図 7:4 推進協会-滞留)。

\section{5. まとめ}

本研究では松本市で開催される「工芸の五月」の運営手法の特徵 を抽出するため、長期運営データの分析を行った。「芸の五月」の 運営組織は、初動期の運営実績をもとに、専門家、行政、民間と連 携を進め、専門的な企画機能を強化した。さらに分業制により運営 の効率化が図られた。次に、全企画から８つのタイプを導出し、民 間と企画室が連携する企画タイプが最も多いことを示した。企画室 が制作する工芸マップなど工芸のまち松本のイメージづくりが民 間企画の導入に有効であることを述べた。さらに、工芸の特性によ 
表 2 企画タイプ ( 全企画 306 中一部抜粋)

\begin{tabular}{|c|c|c|c|c|c|c|c|c|c|c|c|c|}
\hline 企画名 & 企画主体 & 企画形態 & 開催場所 & \begin{tabular}{|l|} 
\\
衣類
\end{tabular} & & 家工 & 芸の & 種類 & & 地域資源 & $\begin{array}{c}\text { 工芸の扱い方 } \\
\text { (ワーシショッフ })\end{array}$ & 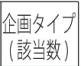 \\
\hline 覟の森ワークショップ 木工体験 & 民間 & 滞留-WS & 民間 - 飲食店 & & & & 0 & & & - & 雑貨-制作 & \\
\hline 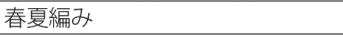 & 民間 & 滞留 - 展示販売 & 民間 - 物販店 & 0 & & & & & & - & & $1-1$ \\
\hline nolxしましま展 & 民間 & 滞留 - 展示販売 & 民間 -その他 & & & & 0 & & & - & & (202) \\
\hline 六九クララトストリート & 民間 & 回遊 & 民間-物販店 & 0 & & 0 & & & & 空き店舗、商店街通り & & $1-2$ \\
\hline 商店と工芸 & 民間 & 回遊 & 民間 - 物販店 & & 0 & 0 & 0 & & 0 & - & & (2) \\
\hline ほろ酔い工芸 2013 & 企画室+民間 & 滞留-WS & 民間 - 物販店 & & & & & & & 地元工房、地元食材 $\cdot$ 酒 & 飲食 & $2-1(1)$ \\
\hline かわいい椅子には旅をさせよ & 企画室十民間 & 回遊 & 民間-物販店 & 0 & 0 & 0 & 0 & & & 地元作家 - & & $2-2(1)$ \\
\hline いとたのし展 & 企画室+公共 & 滞留-展示販売 & 公共-文化 & & & & & 0 & & - & & \\
\hline くらし、いのり & 企画室十公共 & 滞留 - 展示 & 公共-文化 (歴) & & & & & & 0 & 地元作家 & & $3-1$ \\
\hline ゆび編みシュシュとフラワーパーティ & 企画室十公共 & 滞留-WS & 公共-会館 (歴) & & & & 0 & 0 & & 地元作家 & & (81) \\
\hline そらまめ酒造ツアー & 企画室十公共 & 回遊 & 公共-文花+民間 & & 0 & & -1 & $\cdots$ & & 酒造 & 飲食 & $3-2$ \\
\hline みずみずしい日常 2013 & 企画室+公共+専門家 & 回遊。 & 公共-文化+民間 & & . & & O & & & 街中の涌水・境内・建筑等 & 制作、飲食、装飾 & \\
\hline すわりまする & 企面室十行政十天学 & 回遊 & 公共-公園-‥ & & 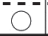 & -1 & 0 & & & 歴史的建造物のレ゙ガ & 制作、飲食、装飾 & $3-3(1)$ \\
\hline クラフトフェアまつもと 2013 & 推進協会 & 滞留 - 展示販売 & 公共 - 公園 & 0 & 0 & $\mathrm{O}$ & 0 & 0 & & 歴史的建造物 & & 4 \\
\hline てのひらに 2013 & 推進協会 & 滞留-展示 & 民間 -その他 & & & & 0 & & & - & & (12) \\
\hline
\end{tabular}

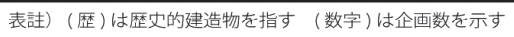
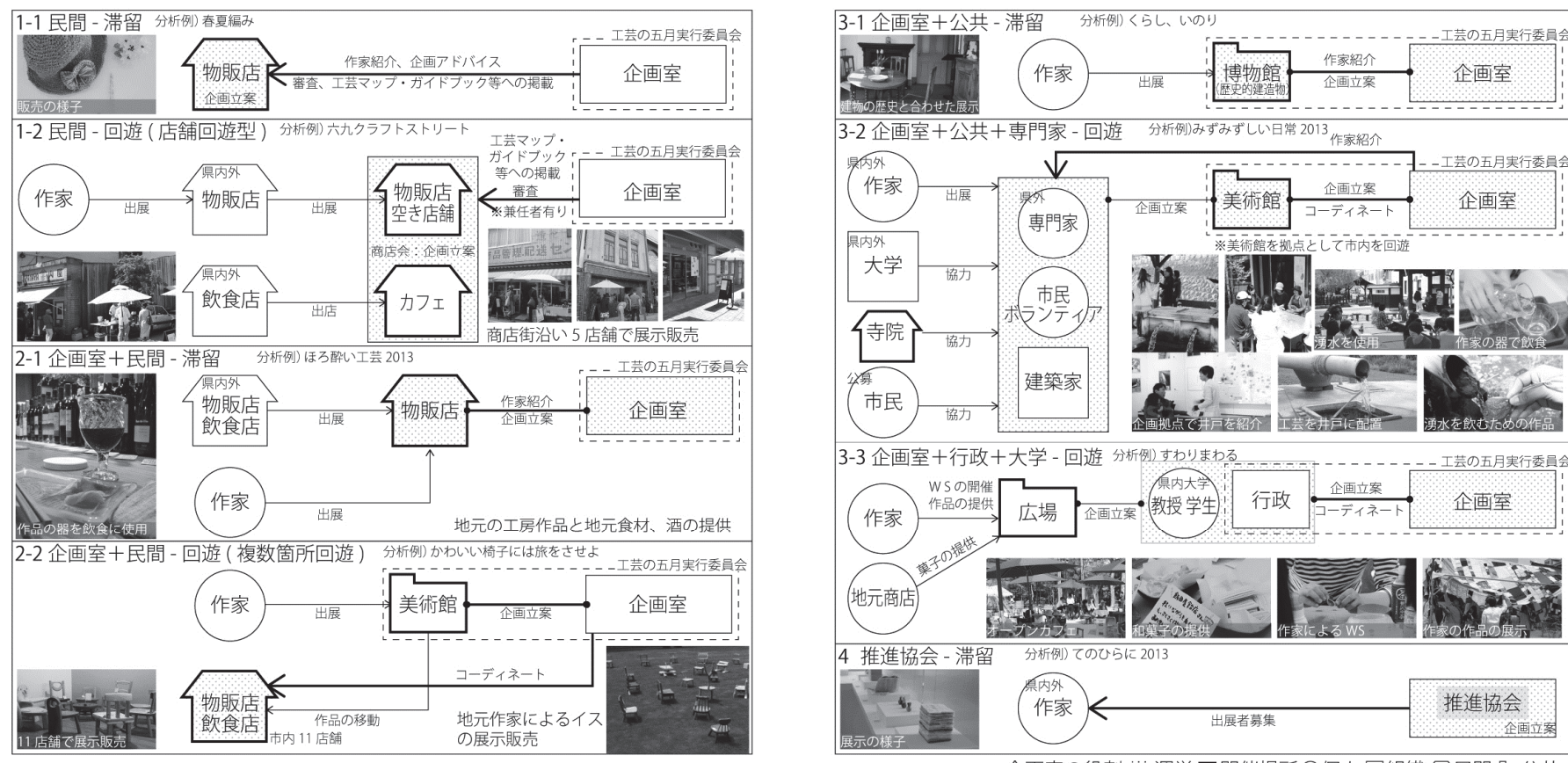

図 7 各企画の運営体制

りギャラリーや飲食店などの民間団体の参入を促進していることを 述べた。以上より、工芸の特性を利用し企画室と民間とが連携する ことで継続的な質の高い運営に成功していると考えられる。

最後に、修士研究として調查に取組んだ高崎茉美氏と調查にご協 力を頂いた倉澤聡氏をはじめ関係各位に心から謝意を表します。

\section{参考文献}

1) 田代利恵 : 文化的イベントが地域協働のまちづくりに果たす役割に関する 研究一古い町並みを有する地方都市を事例に一, 龍谷大学大学院政策学研究 1, 2012. 9

2) 小森宗泰, 野鳴慎二 : 伝統工芸産地における発信型店舗・事業所の成立過程 とそのネットワーク組織に関する研究, 日本建築学会画系論文集, 第 576 号, pp117-124, 2004. 2

3) 平林直: 文化創造活動が都市空間の形成に及ぼす影響に関する研究一松本市 中町のまちづくりと民藝運動の関係-，東京大学修士論文 2007

4) 山根宏文: クラフトフェアまつもとによる経済波及効果報告書, N P O 法人 松本クラフト推進協会, 2012.7

5) 松本市建設部建設総務課：工芸の五月 2012 から 2013 へ 2013.1

6) NP0 法人松本クラフト推進協会工芸の五月企画室:工芸の五月企画書, 2009 7) 松本市 :「工芸のまち松本」構想, 2008. 11

\section{註䣋}

註 1) 伝統工芸や民芸を始めとした歴史的なものから現代の工芸家によるクラ フト、手仕事、雑貨にいたる幅広い概念を持つ。

註 2) 全国では 400 件以上のクラフトフェアが開催されている。全国クラフト フェア一覧 http://tsukoubow. gozaru. jp/craft50onlist. html

註 3) 工芸作家の作品発表と交流、売買の場として 1985 年に開始。日本の クラフトフェアの起源とされる。現在は全国から 1500 以上の応募から審 查により 250 作家が出店。 2 日間で 7 万人が来訪する一大イベントである。 註 4）参考文献 5）6）および市職員、運営に携わる市民へのヒアリングによ る調查、2013.11.23〜12.1

註 5) 参考文献 4）よりクラフトフェアによる経済効果は 18 億円を越える。

註 6) 参考文献 7）より、伝統工芸や民芸、クラフトなどの工芸は松本市のま ちづくりのテーマとされている。

註 7） N PO法人松本クラフト推進協会、松本市（政策部・商工観光部・建 設部・教育部等)、財団法人松本市教育文化振興財団、松本商工会議所、松 本観光コンベンション協会、松本市町会連合会、松本商店街連盟、松本地 区タクシー協議会、松本市駐車場事業協同組合、アルピコ交通株式会社、 東日本旅客鉄道株式会社

註 8) 工芸の五月 http://matsumoto-crafts-month. com 及び市職員、市民組織 関倸者へのヒアリングにより調査、2013.11.23〜12.1

[2015 年 2 月 17 日原稿受理 2015 年 4 月 13 日採用決定］ 